\title{
Indoor Air Quality and Health Outcomes in Employees Working from Home during the COVID-19 Pandemic: A Pilot Study
}

\author{
Taehyun Roh ${ }^{1} \mathbb{D}$, Alejandro Moreno-Rangel ${ }^{2} \mathbb{D}$, Juha Baek ${ }^{3}$, Alexander Obeng ${ }^{4}\left(\mathbb{D}\right.$, Nishat Tasnim Hasan ${ }^{1}$ \\ and Genny Carrillo $4,5, * \mathbb{D}$
}

check for updates

Citation: Roh, T.; Moreno-Rangel, A.; Baek, J.; Obeng, A.; Hasan, N.T.; Carrillo, G. Indoor Air Quality and Health Outcomes in Employees Working from Home during the COVID-19 Pandemic: A Pilot Study. Atmosphere 2021, 12, 1665. https:// doi.org/10.3390/atmos12121665

Academic Editors: Ashok Kumar, M Amirul I Khan, Alejandro Moreno Rangel and Michał Piasecki

Received: 30 November 2021

Accepted: 9 December 2021

Published: 11 December 2021

Publisher's Note: MDPI stays neutral with regard to jurisdictional claims in published maps and institutional affiliations.

Copyright: (c) 2021 by the authors. Licensee MDPI, Basel, Switzerland. This article is an open access article distributed under the terms and conditions of the Creative Commons Attribution (CC BY) license (https:// creativecommons.org/licenses/by/ $4.0 /)$.
1 Department of Epidemiology and Biostatistics, School of Public Health, Texas A\&M University, 212 Adriance Lab Road, College Station, TX 77843, USA; taehyunroh@tamu.edu (T.R.); nishat@tamu.edu (N.T.H.)

2 Lancaster Institute of Contemporary Arts, Faculty of Arts and Social Science, Lancaster University, Bailrigg, Lancaster LA1 4YW, UK; a.morenorangel@lancaster.ac.uk

3 Center for Outcomes Research, Houston Methodist, 7550 Greenbriar Drive, Houston, TX 77030, USA; jbaek@houstonmethodist.org

4 Department of Environmental and Occupational Health, School of Public Health, Texas A\&M University, 212 Adriance Lab Road, College Station, TX 77843, USA; abobeng@tamu.edu

5 Program on Asthma Research and Education, Healthy South Texas, Texas A\&M School of Public Health, McAllen Campus, 2102 S. McColl Road, McAllen, TX 78503, USA

* Correspondence: gcarrillo@tamu.edu

Abstract: Indoor air quality (IAQ) has a substantial impact on public health. Since the beginning of the COVID-19 pandemic, more employees have worked remotely from home to minimize in-person contacts. This pilot study aims to measure the difference in workplace IAQ before and during the pandemic and its impact on employees' health. The levels of fine particulate matter $\left(\mathrm{PM}_{2.5}\right)$ and total volatile organic chemicals (tVOC) were measured in the employees' offices before the COVID-19 pandemic and at homes while working from home during the pandemic using Foobot air monitors. The frequencies of six sick building syndrome (SBS) symptoms were evaluated at each period of monitoring. The result showed $\mathrm{PM}_{2.5}$ levels in households while working from home were significantly higher than in offices while working at the office for all participants $(p<0.05)$. The PM 2.5 levels in all households exceeded the health-based annual mean standard $\left(12 \mu \mathrm{g} / \mathrm{m}^{3}\right)$, whereas $90 \%$ of offices were in compliance. The tVOC levels were all below the standard $\left(500 \mu \mathrm{g} / \mathrm{m}^{3}\right)$. We also found a higher frequency of SBS symptoms were observed while working from home as the IAQ was worse at home. This study suggested that working from home might have a detrimental health impact due to poor IAQ and providing interventions to remote employees should be considered.

Keywords: indoor air quality; air monitor; particulate matter 2.5; COVID-19; employee health; remote work

\section{Introduction}

Indoor air pollution has been classified as one of the top five environmental health hazards. In the United States (US), the average person spends nearly $90 \%$ of their time indoors, where air quality is estimated two to five times worse than outdoors [1]. Indoor air quality (IAQ) is affected by outdoor factors (i.e., motor vehicle and industry), indoor activities (i.e., cooking and smoking) and building-related factors (i.e., ventilation and air conditioning systems) [2].

Outdoor chemicals, including fine particulate matter $\left(\mathrm{PM}_{2.5}\right)$, volatile organic compounds (VOCs), ozone $\left(\mathrm{O}_{3}\right)$, carbon monoxide $(\mathrm{CO})$, and radon could affect IAQ. However, there are a variety of additional sources for indoor air pollution in offices and homes. In offices, most indoor pollutants are related to building materials and human activities such as carpet and other office furniture, cleaning agents, air fresheners, paints, adhesives, printers, 
pesticides, and biological contaminants from poor ventilation systems or water-damaged walls [3-6]. A study conducted by Serafin et al. prioritized the indoor air pollutants in office buildings and found formaldehyde, acetaldehyde, benzene, $\mathrm{PM}_{2.5}$, and $\mathrm{PM}_{10}$ as priority pollutants [7]. In households, activities performed by individuals including cooking, laundry, smoking, and the use of chemicals for cleaning and hobbies increase indoor air pollution [8]. The primary indoor air pollutants include particulate matter, volatile organic compounds (VOCs), semi-volatile organic compounds (SVOCs), ozone, asbestos, tobacco smoke, nonpolar volatile organic compounds, allergens, and mold [9,10].

Modern buildings are designed to be airtight, eliminating natural ventilation as they are controlled by heating, ventilation, and air conditioning (HVAC) systems that recirculate a high percentage of the air with minimal fresh air replacement, maintaining constant IAQ across seasons [10-12]. HVAC systems have a critical role in keeping people inside buildings comfortable and healthy, and they are intended to provide an air supply to the room and have an exhaust system to remove dirty air from indoor spaces [13]. Nonresidential buildings like offices usually have an mechanical ventilation for outdoor air change, with less natural ventilation or infiltration contribution, maintaining constant IAQ over seasons [14]. It is recommended to install filters (F7 grade or above) to filter fresh air to the unit to protect HVAC units and limit the ingress of outdoor particles. However, inadequate system installation and poorly maintained air ducts and filters diminish the air quality [15]. Biological particles such as bacteria, fungi, and viruses correlated with respiratory health conditions can float in the air and linger longer in poorly ventilated indoor spaces [16-18].

IAQ is a significant concern because it could adversely impact human health, comfort, well-being, and productivity [19]. Acute and chronic health effects are associated with exposure to indoor air pollutants in office environments. Sick building syndrome (SBS) is a group of acute adverse health experiences related to IAQ, including headache, eye irritation, dry cough, and itching skin for occupants of a building related to the time spent in the building $[20,21]$. According to a multi-country study in Europe, the most prevalence adverse health outcomes were dry eyes and headache, accounting for one-third of the office workers [22]. In the US, SBS could be responsible for an overall loss in productivity, leading to costs up to $\$ 75$ billion per year [23]. Poor IAQ also increases the risk of chronic health problems including cardiovascular disease, chronic obstructive and pulmonary disease, and lung cancer [24]. Among indoor air pollutants, $\mathrm{PM}_{2.5}$ has become a major public health hazard because it penetrates deeply into the respiratory trat, entering the circulatory system and causing oxidative stress and inflammation [25-28]. Among indoor air pollutants, $\mathrm{PM}_{2.5}$ is a dominant indoor air pollutant causing 4000 DALYs (disability-adjusted life years) per one million population, which is $80 \%$ of the total annual burden of diseases related to indoor exposure [29].

The development of information and communication technologies have changed the work environment, increasing the adaptation of remote work in diverse occupations including managers, educators, and those working in computers, finance, and law [30,31]. In Europe, the proportion of teleworkers was less than $10 \%$ in normal times, which increased up to $31 \%$ during the COVID-19 pandemic [32]. In the US, the percentage of employees who had ever worked remotely increased from 9\% in 1995 to 37\% in 2015 and the average number of days working remotely per month was 2.3 [33]. The advantages of remote work include flexibility, cost and time savings on commuting, and more time with family $[34,35]$. In contrast, it also has negative aspects such as loss of social interaction and self-discipline and unfavorable physical conditions, leading to productivity reduction and psychological and psychological distress [36-38].

In December 2019, the COVID-19, caused by a new coronavirus, SARS-CoV-2, was first detected in Wuhan, China [39]. The World Health Organization (WHO) proclaimed the COVID-19 outbreak to be the sixth global public health emergency on 30 January $2020[40,41]$. Due to the highly contagious nature of the disease, governments decided to implement "social distancing" measures, closing businesses and enacting stay-at-home 
orders [42]. Some sectors of occupations such as healthcare, farm, construction, and service workers could not be carried out remotely, and therefore had higher risks of contracting COVID-19 [43]. In contrast, many employees in fields including management, education, and information technology worked remotely during 2020 and half of 2021 [31,44-46]. In the US, approximately $30 \%$ of employees changed to working from home between February and May 2020 [47]. In Canada, the percentage of remote workers increased from $13 \%$ to $39 \%$ during March 2020 [48]. In the Netherlands, $6 \%$ of workers worked from home before the pandemic, but the percentage increased to 39\% during the pandemic [49]. However, the domestic spaces became offices without consideration of environmental infrastructures such as ventilation systems and subsequent indoor air quality, posing health risks to employees [50].

This study aims to evaluate the IAQ in the office before the COVID-19 pandemic and at home while working remotely from home during the pandemic and compare the health outcomes in employees between those two periods.

\section{Materials and Methods}

\subsection{Participants and Study Design}

This pilot study was conducted in McAllen, South Texas, during May-July 2019 in employees' offices before the COVID-19 pandemic and during June-September 2020 at their households while employees worked from home during the pandemic. A total of eight staff members working in the same building in an academic organization participated in the study. The study protocol was reviewed and approved by Texas A\&M University's Institutional Review Boards. The methodology presented here was adapted to comply with the COVID-19 regulation from a previous study from our research group [51].

\subsection{Air Quality Assessment}

This study used a low-cost consumer monitor called Foobot ${ }^{\circledR}$ Air Monitor (Model\# FBT0002100, AirBoxLab, San Francisco, CA, USA) to assess the IAQ in the offices and households. The performance and accuracy of the Foobot monitor were assessed and determined to be a reliable tool for measuring indoor pollution levels $[52,53]$. The Foobots (low-cost air monitors) were used in the offices and homes (bedroom, kitchen, and living room), where occupants stay for a longer time [54]. As suggested in previous studies, calibration equations, data quality, and data corroboration were followed by comparison $[55,56]$. The IAQ was measured according to the ASTM D7297-14. The Foobot monitors (air temperature $\left(-40-125{ }^{\circ} \mathrm{C}\right)$, relative humidity $(0-100 \%), \mathrm{PM}_{2.5}\left(0-1300 \mu \mathrm{g} / \mathrm{m}^{3}\right)$, and tVOC (100-1000 ppb) were installed in each office on top of a bookshelf (5-6 feet). The Foobot air monitors collected data at 5-minute intervals for two months in each office. The same procedure was done in households to avoid any accidents with children living at the house. We used hotspots in both locations to have a stable WiFi connection throughout the study periods. The data was stored automatically every five minutes in a protected online storage and were safely saved in an encrypted computer.

The outdoor temperature and $\mathrm{PM}_{2.5}$ levels in the study area during the same periods of IAQ measurements were retrieved from the Texas Air Monitoring Information System (TAMIS), a database maintained by the Texas Commission on Environmental Quality (TCEQ). The outdoor tVOC levels were not collected because data were not available.

\subsection{Health Outcomes Assessment}

A brief version of the modified Office Environment Survey (OES) was implemented for all participants to assess six SBS symptoms while they were working in the office before the COVID pandemic and at home during the pandemic as well as the characteristics of residential environment and behaviors in the participants' homes [57]. The selected six SBS symptoms included in this study were: dry eyes, itchy or watery eyes, blocked or stuffy nose, dry throat, headache, and dry or irritated skin, as these were identified as more dominant and prevalent from previous studies [56-59]. The frequencies of these 
symptoms were assessed using a Likert scale, and scores for each symptom were assigned by the frequency of symptoms: 0 (not at all), 1 (less often), 2 (every 2-3 weeks), 3 (1-2 days each week), 4 (3-4 days each week) and 5 (every day). The surveys were conducted online via Qualtrics.

\subsection{Statistical Analysis}

The least-square geometric means (LSGMs) for $\mathrm{PM}_{2.5}$ and $\mathrm{tVOC}$ levels were calculated from the data collected at 5-minute intervals for each monitoring period in the offices and the three locations (bedroom, kitchen, and living room) within the homes. After adjusting for temperature and relative humidity, the generalized linear model was fitted to estimate LSGMs and 95\% confidence intervals (CIs) of $\mathrm{PM}_{2.5}$ and $\mathrm{tVOC}$ levels and compare those levels in the offices while working at the office before the COVID-19 pandemic and at homes working from home during the pandemic in each participant and overall. The differences in levels of those pollutants among locations within the houses were assessed using Tukey's post hoc test. However, for health outcomes, statistical analyses could not be conducted for their associations with IAQ due to the small sample size. Instead, the direction of changes in IAQ and frequencies of health outcomes were manually compared between the two periods for each participant. All statistical analyses were conducted using SAS version 9.4 (SAS Institute Inc., Cary, NC, USA). A p-value less than 0.05 was considered statistically significant.

\section{Results}

In our study, eight female academic staff members aged 23 to 67 years old (average 36.1, standard deviation 13.1) participated. All participants lived in single-family detached houses with central air conditioning systems and electric heaters. All households had electric dryers vented outside and kitchen fans, and none of their family members smoked or worked with hazardous materials on the job. Table 1 summarizes other characteristics of the residential environment and behaviors in the participants' home. The average numbers of rooms and people living in the house were 3.3 and 3.4. Six homes had furry pets and non-carpeted floors at their homes. Seven families used electronic stoves and bathroom fans, and three households had air purifiers. Most households rarely opened windows for ventilation and only three households cleaned their floors regularly using a vacuum cleaner. Five houses used chemicals for lawn care. The averages of indoor temperature and relative humidity measured at homes during the study period were $24.6{ }^{\circ} \mathrm{C}$ (range: 23.6-26.9) and 52.8\% (range: 46.3-57.5), which are within the recommended ranges of indoor temperature $\left(23-27^{\circ} \mathrm{C}\right)$ and relative humidity $(30-60 \%)[60,61]$.

Table 1. Characteristics of residential environment and behaviors in the participants' homes.

\begin{tabular}{|c|c|c|c|c|c|c|c|c|c|c|c|c|}
\hline Participants & $\begin{array}{l}\text { No. of } \\
\text { Rooms }\end{array}$ & $\begin{array}{c}\text { No. of } \\
\text { Family } \\
\text { Members }\end{array}$ & Floor Material & Pet & Stove & $\begin{array}{l}\text { Bathroom } \\
\text { Fan }\end{array}$ & Air Purifier & $\begin{array}{c}\text { Window } \\
\text { Ventilation } 1\end{array}$ & $\begin{array}{l}\text { Vacuum } \\
\text { Cleaning }\end{array}$ & $\begin{array}{l}\text { Lawn } \\
\text { Chemical }\end{array}$ & $\begin{array}{l}\text { Temperature } \\
\left({ }^{\circ} \mathrm{C}\right)(\mathrm{SD})\end{array}$ & $\begin{array}{l}\text { Relative } \\
\text { humidity } \\
\text { (\%) (SD) }\end{array}$ \\
\hline 1 & 5 & 5 & Tile & $\mathrm{Y}$ & Electric & Y & $\mathrm{N}$ & $1-2$ & $\mathrm{~N}$ & Y & $24.4(1.9)$ & $54.3(3.2)$ \\
\hline 2 & 4 & 2 & Hardwood & $\mathrm{N}$ & Electric & $\mathrm{N}$ & $\mathrm{Y}$ & $1-2$ & $\mathrm{~N}$ & Y & $22.7(1.5)$ & $53.5(3.2)$ \\
\hline 3 & 3 & 3 & $\begin{array}{l}\text { Tile } \\
\text { The }\end{array}$ & $\mathrm{Y}$ & Electric & $\mathrm{Y}$ & $\mathrm{N}$ & $1-2$ & $\mathrm{~N}$ & Y & $24.7(2.0)$ & $46.3(3.5)$ \\
\hline 4 & 3 & 5 & $\begin{array}{l}\text { Completely } \\
\text { carpeted }\end{array}$ & $\mathrm{N}$ & Electric & $\mathrm{Y}$ & $\mathrm{N}$ & Never & Y & $\mathrm{N}$ & $22.9(1.4)$ & $52.8(3.8)$ \\
\hline 5 & 3 & 4 & Hardwood & $\mathrm{Y}$ & Electric & $\mathrm{Y}$ & $\mathrm{N}$ & Never & $\mathrm{N}$ & $\mathrm{Y}$ & $25.8(1.2)$ & $56.5(6.4)$ \\
\hline 6 & 3 & 2 & Tile & $\mathrm{Y}$ & Electric & $\mathrm{Y}$ & $\mathrm{N}$ & Never & $\mathrm{Y}$ & $\mathrm{N}$ & $23.6(0.8)$ & $48.9(3.3)$ \\
\hline 7 & 5 & 4 & Tile & Y & Gas & Y & $\mathrm{Y}$ & Never & $\mathrm{N}$ & $\mathrm{Y}$ & $26.9(1.7)$ & $57.5(4.0)$ \\
\hline 8 & 0 & 2 & Partially carpeted & $\mathrm{Y}$ & Electric & Y & $\mathrm{Y}$ & Never & Y & $\mathrm{N}$ & $25.4(0.7)$ & $52.2(1.7)$ \\
\hline
\end{tabular}

${ }^{1}$ Frequency per one month.

Table 2 shows the averages of $\mathrm{PM}_{2.5}$ levels in the offices before the COVID-19 pandemic and at homes during the pandemic for each participant. The results showed that the averages of indoor $\mathrm{PM}_{2.5}$ levels ranged from $5.6-12.2 \mu \mathrm{g} / \mathrm{m}^{3}$ for offices and $11.2-45.7 \mu \mathrm{g} / \mathrm{m}^{3}$ for homes in our participants. The $\mathrm{PM}_{2.5}$ concentration levels at homes during the pandemic were significantly higher than those in the offices before the pandemic for each participant. Six homes had levels higher than the current health-based standard $\left(12 \mu \mathrm{g} / \mathrm{m}^{3}\right)$ of the National Ambient Air Quality Standards (NAAQS) [62], whereas one office had $\mathrm{PM}_{2.5}$ 
levels higher than this level. Only one participant had $\mathrm{PM}_{2.5}$ levels higher than the national standard in both the office and home.

Table 2. Averages of indoor $\mathrm{PM}_{2.5}$ levels $\left(\mu \mathrm{g} / \mathrm{m}^{3}\right)$ in the offices before the COVID-19 pandemic and at homes during the pandemic (LSGMs, $95 \% \mathrm{CI}$ ).

\begin{tabular}{ccc}
\hline Participants & Office & Home \\
\hline $1^{*}$ & $8.95(8.78-9.13)$ & $22.5(22.3-22.8)$ \\
$2^{*}$ & $4.28(4.09-4.28)$ & $45.7(45.2-46.2)$ \\
$3^{*}$ & $8.03(7.99-8.08)$ & $14.8(14.7-14.8)$ \\
$4^{*}$ & $7.36(7.28-7.44)$ & $12.2(12.1-12.3)$ \\
$5^{*}$ & $9.78(9.72-9.85)$ & $11.2(11.2-11.3)$ \\
$6^{*}$ & $7.93(7.83-8.02)$ & $16.8(16.7-16.9)$ \\
$7^{*}$ & $12.2(12.1-12.4)$ & $13.3(13.2-13.3)$ \\
$8^{*}$ & $5.60(5.49-5.71)$ & $11.5(11.5-11.6)$ \\
Total $^{*}$ & $8.18(7.48-8.95)$ & $16.3(12.4-21.3)$ \\
\hline
\end{tabular}

${ }^{*} \mathrm{PM}_{2.5}$ level in the household was significantly higher than the office at $p<0.05$.

Table 3 describes the mean $\mathrm{PM}_{2.5}$ levels for different locations such as the bedroom, kitchen, and living room in each home. Bedroom $\mathrm{PM}_{2.5}$ levels ranged from $9.95-94.51 \mu \mathrm{g} / \mathrm{m}^{3}$ compared to $10.87-22.58 \mu \mathrm{g} / \mathrm{m}^{3}$ for kitchens and $8.89-29.71 \mu \mathrm{g} / \mathrm{m}^{3}$ for living rooms. In four homes (50\%), the $\mathrm{PM}_{2.5}$ levels were highest in the bedrooms compared to the kitchens and living rooms of the same home. The levels of $\mathrm{PM}_{2.5}$ were highest in the kitchen (participants 6 and 8) and the living room (participant 5) compared to the other two locations within the same home. At homes of six participants (75\%), the levels of $\mathrm{PM}_{2.5}$ in the living room were significantly lower than in other locations.

Table 3. Averages of $\mathrm{PM}_{2.5}$ levels $\left(\mu \mathrm{g} / \mathrm{m}^{3}\right)$ at different locations in the households (LSGMs and $95 \%$ CI).

\begin{tabular}{cccc}
\hline Participants & Bedroom & Kitchen & Living Room \\
\hline 1 & $80.15(79.23-81.09)^{*}$ & $16.90(16.66-17.16)$ & $12.33(12.23-12.44)^{\dagger}$ \\
2 & $94.51(93.03-96.00)^{*}$ & $22.58(22.21-22.96)^{\dagger}$ & $29.71(29.15-30.29)$ \\
3 & $17.79(17.65-17.94)^{*}$ & $15.81(15.68-15.93)$ & $11.40(11.33-11.47)^{\dagger}$ \\
4 & $13.04(12.84-13.26)$ & $13.05(12.90-13.20)$ & $11.37(11.23-11.52)^{\dagger}$ \\
5 & $9.73(9.68-9.79)^{\dagger}$ & $10.87(10.78-10.96)$ & $12.79(12.67-12.90)^{*}$ \\
6 & $15.61(15.37-15.85)$ & $20.65(20.36-20.95)^{*}$ & $14.30(14.08-14.52)^{\dagger}$ \\
7 & $21.09(20.89-21.28)^{*}$ & $18.39(18.23-18.54)$ & $10.85(10.75-10.95)^{\dagger}$ \\
8 & $9.95(9.78-10.13)$ & $15.25(15.05-15.46)^{*}$ & $8.89(8.80-8.99)^{\dagger}$ \\
\hline
\end{tabular}

${ }^{*} \mathrm{PM}_{2.5}$ level at the location was significantly higher than other locations at $p<0.05 .{ }^{\dagger} \mathrm{PM}_{2.5}$ level at the location was significantly lower than other locations at $p<0.05$.

Table 4 describes the average tVOC levels in the offices and homes for all participants. The average tVOC levels ranged from $151.65-215.08 \mu \mathrm{g} / \mathrm{m}^{3}$ for offices and $152.87-279.86 \mu \mathrm{g} / \mathrm{m}^{3}$ for homes. The tVOC levels were significantly higher at homes than in the offices for all participants. However, all the tVOC levels in the offices and homes were much lower than the acceptable maximum tVOC level of $500 \mu \mathrm{g} / \mathrm{m}^{3}$ [63].

Additional analyses showed that the average $\mathrm{tVOC}$ levels within the house ranged from $159.4-305.2 \mu \mathrm{g} / \mathrm{m}^{3}$ in the bedrooms, $151.1-286.1 \mu \mathrm{g} / \mathrm{m}^{3}$ in the kitchens, and 148.9$273.8 \mu \mathrm{g} / \mathrm{m}^{3}$ in the living rooms (Table 5). The tVOC levels at all locations within homes were much lower than the acceptable maximum level of $500 \mu \mathrm{g} / \mathrm{m}^{3}$ [63]. In four homes $(50 \%)$, the tVOC levels were highest in the bedrooms compared to the kitchens and living rooms of the same home. The $\mathrm{VOC}$ levels were highest in the kitchen (participants 1, 3, and 5) and the living room (participants 2 and 7) compared to the other two locations within the same home. 
Table 4. Averages of indoor tVOC levels $\left(\mu \mathrm{g} / \mathrm{m}^{3}\right)$ in the offices before the COVID-19 pandemic and at homes during the pandemic (LSGMs, 95\% CI).

\begin{tabular}{ccc}
\hline Participants & Office & Home \\
\hline $1^{*}$ & $166.68(164.63-168.76)$ & $253.48(251.97-255.03)$ \\
$2^{*}$ & $172.71(171.28-174.15)$ & $181.27(180.53-182.00)$ \\
$4^{*}$ & $168.38(167.10-169.66)$ & $242.89(241.65-244.13)$ \\
$5^{*}$ & $173.78(171.95-175.63)$ & $279.86(278.22-281.55)$ \\
$6^{*}$ & $215.08(213.47-216.70)$ & $222.05(221.16-222.94)$ \\
$7^{*}$ & $164.66(163.01-166.33)$ & $230.00(228.38-231.67)$ \\
$8^{*}$ & $151.65(149.71-153.61)$ & $229.11(227.69-230.56)$ \\
Total * & $168.31(166.88-169.73)$ & $152.87(152.49-153.27)$ \\
${ }^{*}$ The tVOC level in the household was significantly higher than the office at $p<0.05$.
\end{tabular}

Table 5. Averages of $\mathrm{tVOC}$ levels $\left(\mu \mathrm{g} / \mathrm{m}^{3}\right)$ at different locations in the households (LSGMs and $95 \% \mathrm{CI})$.

\begin{tabular}{cccc}
\hline Participants & Bedroom & Kitchen & Living Room \\
\hline 1 & $228.38(225.02-231.78)$ & $286.12(280.82-291.52) *$ & $228.40(225.92-230.90)$ \\
2 & $184.97(183.66-186.29)^{*}$ & $168.95(167.70-170.20)^{+}$ & $178.68(177.15-180.22)^{*}$ \\
3 & $228.31(225.34-231.32){ }^{+}$ & $264.36(260.99-267.76)^{*}$ & $239.27(236.89-241.68)$ \\
4 & $305.24(300.28-310.29)^{*}$ & $270.70(267.52-273.88)$ & $273.77(270.35-277.22)$ \\
5 & $226.92(225.23-228.63)^{+}$ & $245.77(243.18-248.39) *$ & $236.35(233.67-239.08)$ \\
6 & $237.75(234.09-241.46)^{*}$ & $219.36(216.24-222.54)$ & $222.54(222.05-229.06)$ \\
7 & $200.58(198.58-202.57)^{+}$ & $209.91(208.03-211.81)$ & $223.86(221.67-226.08)^{*}$ \\
8 & $159.41(158.17-160.68)^{*}$ & $151.11(150.19-152.03)$ & $148.89(148.19-149.59)^{\dagger}$ \\
\hline
\end{tabular}

* The tVOC level at the location was significantly higher than other locations at $p<0.05 .{ }^{+}$The tVOC level at the location was significantly lower than other locations at $p<0.05$.

Table 6 shows the changes in the frequency of six SBS symptoms associated with poor air quality that participants reported. Among six participants who completed the health survey at both periods, four subjects reported higher frequency of multiple symptoms while working at home than while working in the office. The $\mathrm{PM}_{2.5}$ level while working at home during COVID-19 (greater than the standard $12 \mu \mathrm{g} / \mathrm{m}^{3}$ ) was higher than at the office before the COVID-19 pandemic (less than the standard $12 \mu \mathrm{g} / \mathrm{m}^{3}$ ). However, in participants 5 and 7, despite the statistically significant difference, both office and home $\mathrm{PM}_{2.5}$ levels were lower or higher than the standard $12 \mu \mathrm{g} / \mathrm{m}^{3}$, and the frequencies of symptoms in these participants were stable between the two different time periods.

Table 6. Frequencies of experiencing six SBS symptoms while working in the office before COVID-19 pandemic and working at home during the pandemic.

\begin{tabular}{|c|c|c|c|c|c|c|c|c|c|c|c|c|c|c|c|}
\hline \multirow{2}{*}{ Participants } & \multicolumn{2}{|c|}{ Dry Eyes } & \multicolumn{2}{|c|}{ Itchy or Watery Eyes } & \multicolumn{2}{|c|}{ Blocked or Stuffy Nose } & \multicolumn{2}{|c|}{ Dry Throat } & \multicolumn{2}{|c|}{ Headache } & \multicolumn{2}{|c|}{$\begin{array}{c}\text { Dry or } \\
\text { Irritated Skin }\end{array}$} & \multicolumn{3}{|c|}{ Number of Symptoms Changed * } \\
\hline & Office & Home & Office & Home & Office & Home & Office & Home & Office & Home & Office & Home & Increased & $\begin{array}{c}\text { No } \\
\text { Change }\end{array}$ & Decreased \\
\hline 1 & 3 & 5 & 3 & 5 & 1 & 5 & 1 & 4 & 1 & 4 & 1 & 4 & 6 & 0 & 0 \\
\hline 2 & 0 & 2 & 0 & 2 & 0 & 1 & 0 & 0 & 0 & 3 & 0 & 4 & 5 & 1 & 0 \\
\hline 3 & 0 & 5 & 0 & 5 & 2 & 5 & 0 & 4 & 3 & 1 & 0 & 3 & 5 & 0 & 1 \\
\hline 5 & 3 & 3 & 0 & 1 & 0 & 0 & 0 & 0 & 1 & 0 & 0 & 0 & 1 & 4 & 1 \\
\hline 6 & 0 & 0 & 0 & 0 & 3 & 4 & 0 & 0 & 3 & 1 & 2 & 3 & 2 & 3 & 1 \\
\hline 7 & 2 & 3 & 3 & 3 & 3 & 3 & 3 & 0 & 0 & 0 & 0 & 0 & 1 & 4 & 1 \\
\hline
\end{tabular}

Each score means the frequency of symptoms: 0 (not at all), 1 (less often), 2 (every 2-3 weeks), 3 (1-2 days each week), 4 (3-4 days each week), and 5 (every day). * Change in the frequencies of the symptoms while working from home during the COVID-19 pandemic, compared to those while working in the office before the pandemic.

Table 7 displays the averages of outdoor temperatures and $\mathrm{PM}_{2.5}$ levels in the study area before and during the COVID-19 pandemic for the same periods of office and home IAQ measurements for each participant. In all participants, outdoor air quality while working at home during the pandemic was significantly better than in the office before the pandemic. The outdoor $\mathrm{PM}_{2.5}$ levels before the pandemic were significantly higher than 
the current national standard of $12 \mu \mathrm{g} / \mathrm{m}^{3}$, whereas those during the pandemic were below the standard. The outdoor temperatures during the pandemic were lower than those before the pandemic. Study participants' homes and offices were in the same or neighboring areas, and therefore there was no difference in outdoor air conditions among the participants.

Table 7. Averages of outdoor temperature $\left({ }^{\circ} \mathrm{C}\right)$ and $\mathrm{PM}_{2.5}$ levels $\left(\mu \mathrm{g} / \mathrm{m}^{3}\right)$ in the study area while working in the office before the COVID-19 pandemic and working from home during the pandemic (LSGMs and 95\% CI).

\begin{tabular}{|c|c|c|c|c|}
\hline \multirow[b]{2}{*}{ Participants } & \multicolumn{2}{|c|}{ Temperature $\left({ }^{\circ} \mathrm{C}\right)$} & \multicolumn{2}{|c|}{$\mathrm{PM}_{2.5}$ Levels $\left(\mu \mathrm{g} / \mathrm{m}^{3}\right)$} \\
\hline & $\begin{array}{c}\text { Before } \\
\text { COVID-19 }\end{array}$ & $\begin{array}{c}\text { During } \\
\text { COVID-19 }\end{array}$ & $\begin{array}{c}\text { Before } \\
\text { COVID-19 }\end{array}$ & $\begin{array}{c}\text { During } \\
\text { COVID-19 }\end{array}$ \\
\hline 1 & $29.9(29.5-30.2)$ & $29.7(29.3-30.2)$ & $13.9(12.2-15.7)$ & $8.53(6.98-10.4)$ * \\
\hline 2 & $28.6(27.9-29.3)$ & $28.0(27.1-28.9)$ & $14.1(12.5-15.9)$ & $8.53(6.93-10.5)$ * \\
\hline 3 & $30.1(29.5-30.9)$ & $27.9(27.2-28.7)$ * & $13.4(11.7-15.4)$ & $8.36(6.78-10.3)$ * \\
\hline 4 & $30.1(29.7-30.6)$ & $29.7(29.2-31.1)$ & 13.6 (11.7-15.7) & $8.49(6.92-10.4)$ * \\
\hline 5 & $28.6(27.9-29.3)$ & $28.0(27.2-28.8)$ & $14.1(12.5-15.9)$ & $7.85(6.54-9.43)$ * \\
\hline 6 & $25.1(24.3-26.1)$ & $25.6(24.4-27.0)$ & $12.1(10.5-14.0)$ & $7.44(5.97-9.28)$ * \\
\hline 7 & $30.1(29.7-30.5)$ & $28.6(28.2-29.1)$ * & $13.4(11.3-15.9)$ & $10.6(8.52-13.2)$ * \\
\hline 8 & $30.0(29.2-30.9)$ & $29.6(29.1-30.2)$ & $13.1(10.1-17.1)$ & $8.51(6.92-10.5)$ * \\
\hline Total & $29.0(28.8-29.3)$ & $28.4(28.1-28.7)$ * & $13.2(12.6-13.8)$ & $8.47(7.97-9.00)$ * \\
\hline
\end{tabular}

* The values during the COVID-19 pandemic were significantly lower than the office at $p<0.05$.

\section{Discussion}

The advent of COVID-19 caused the shift of working pattern to work from home remotely for many employees. However, homes may not be a good working environment, compared to conventional office settings with better air conditioning and ventilation systems [4]. In addition, activities performed by individuals at homes may increase indoor air pollution, contributing to more negative health issues [8]. Therefore, in this pilot study, IAQ in the offices before the COVID-19 pandemic and at homes during the pandemic and employees' health status in both periods were compared to assess the impact of working from home on employees' health during the pandemic. Our study found that the IAQ in households during the pandemic was worse than that in the office before the pandemic in all participants, and participants experienced higher frequency of SBS symptoms while working from home. Specifically, home IAQ was worse than the outdoor air quality, and the $\mathrm{PM}_{2.5}$ levels in all households while working from home were greater than the health-based standard $12 \mu \mathrm{g} / \mathrm{m}^{3}$.

The interest in studying the impact of COVID-19 in different settings has led to higher scrutiny of the IAQ at homes during the lockdown. A recent study conducted in Northern Italy estimated the average indoor $\mathrm{PM}_{2.5}$ levels ranged from 8.6 to $18.7 \mu \mathrm{g} / \mathrm{m}^{3}$, which were higher than the outdoor $\mathrm{PM}_{2.5}$ levels $\left(7.4-15.4 \mu \mathrm{g} / \mathrm{m}^{3}\right)$ for a two-week study period in summer during the lockdown [4]. In a study conducted in Norway, the IAQ in home offices were evaluated for up to two weeks, and levels of $\mathrm{CO}_{2}$ and other pollutants higher than health-based standards were detected [50]. Our findings were consistent with previous studies to investigate the IAQ at homes during the COVID-19 pandemic. However, previous studies only focused on home IAQ during the pandemic without comparing with IAQ in the office before the pandemic and the IAQ was measured for shorter time periods ( 2 weeks) than our study ( 2 months), and the health impact was not evaluated directly from the participants.

One of the strengths of our study is that evaluating IAQ in the office before the pandemic and that at home during the pandemic in the same individuals in the same season enabled us to compare personal exposure to air pollutants. In addition, their health status during those two different periods was directly assessed in each individual to investigate the negative health impact of the COVID-19 pandemic. Another strength of this study is the utilization of a low-cost Foobot air monitor, for which reliability and accuracy 
in collecting temporal and spatial IAQ data were validated in previous studies [51-53]. This monitor provides real-time data and was helpful to monitor multiple locations at home simultaneously, allowing longitudinal monitoring for months in each period. In addition, the user-friendly interface requiring low maintenance and power consumption allows participants to install it quickly without a researcher's visit to their homes when social distancing was in place.

There are several limitations to our study. First, due to the small sample size, we could not conduct a statistical analysis to investigate the comprehensive association between IAQ and health outcomes, adjust for characteristics of residential environments and behavioral factors, and differentiate the influences of multiple factors on health complaints. Although the changes of frequencies of health outcomes were in the same direction and degree of changes of $\mathrm{PM}_{2.5}$, larger sample sizes should be considered to perform statistical analyses in future studies. However, the IAQ was measured at 5-minute intervals for 2 months at each location before and during the pandemic, and there were enough numbers of measurements for statistical analyses, demonstrating a significantly worse air quality at homes of all individual subjects during the pandemic, regardless of home environments. Second, the Foobot air monitor did not measure the outdoor air pollutants simultaneously because this monitor is not suitable for outdoor measurements. However, we collected the daily outdoor temperature and $\mathrm{PM}_{2.5}$ data in our study area from TCEQ during the study periods. We found the outdoor $\mathrm{PM}_{2.5}$ levels were significantly lower while working from home during the pandemic, which is consistent with other studies showing the reduction of ambient air pollution globally during the pandemic [64]. This indicates that the outdoor $\mathrm{PM}_{2.5}$ levels did not confound the exacerbation of symptoms caused by home IAQ. Third, IAQ measurements were not conducted during the whole year and seasonal and temporal changes could not be addressed. In South Texas, the $\mathrm{PM}_{2.5}$ levels were highest in summer, due to the hot and humid climate, and lowest in winter, and residents may experience more symptoms in summer and less in winter [65]. However, the seasonal difference could be excluded by assessing and comparing IAQ and health complaints in the same season. Fourth, the health outcome was assessed by self-report surveys, leading to recall biases. Finally, the effects of other behavioral factors could affect our findings. For example, some symptoms such as headache or dry eyes could be related to the increased screen time from telework [66], and other studies proposed that increased sedentary behaviors and reduced physical activity may increase the susceptibility to adverse health outcomes [46,67].

Despite these limitations, IAQ and health outcomes were measured in the office and household of the same participants, providing a unique opportunity to gather some limited but essential information, allowing the comparison of two different work environments. Especially, our findings provided us with information on whether employers need to provide a healthy place at home for a remote worker and such intervention will be possible with reasonable costs to protect and improve the health of all employees. Further large-scale studies should be conducted by addressing the limitations discussed earlier.

\section{Conclusions}

This pilot study assessed workplace IAQ and SBS symptoms before and during the COVID-19 pandemic in academic administrative staff members whose workplace changed from office to home due to the pandemic. Low-cost sensors were found suitable for in situ and continuous IAQ monitoring due to their simplicity, speed, and data accessibility. This study found that working from home may cause greater health issues for employees due to poor home IAQ, emphasizing the importance of the interventions to improve the home IAQ. One of the recommendations to enhance IAQ at homes can be achieved through behavioral changes such as opening windows and doors unless the outdoor air quality is harmful. Another approach is to provide remote workers with portable air purifiers with HEPA filters, particularly in locations where appropriate ventilation is difficult to attain. Lastly, integrating these strategies with smart building technologies would maximize the health and wellness of building occupants. 
Author Contributions: Study design and conceptualization, G.C.; data analysis and interpretation, T.R., A.M.-R., A.O., and J.B.; writing—original draft preparation, T.R., A.O., J.B., N.T.H., and G.C.; writing-review and editing, A.M.-R., J.B., T.R., N.T.H., and G.C.; project administration and funding acquisition, G.C. All authors have read and agreed to the published version of the manuscript.

Funding: This research was funded by Research England's Expanding Excellence in England (E3) Fund, the National Institute of Environmental Health Sciences (P30 ES029067), and the State of Texas's legislative action to establish and support the Healthy South Texas Initiative. Funds were administered through Texas A\&M University Health Science Center (grant number 23-183000).

Institutional Review Board Statement: The study was conducted according to the guidelines of the Declaration of Helsinki, and approved by the Institutional Review Board of Texas A\&M University's Institutional Review Boards reviewed and approved the study protocol.

Informed Consent Statement: Informed consent was obtained from all subjects involved in the study.

Data Availability Statement: The data used to support the findings of this study are available from the corresponding author upon request.

Acknowledgments: The authors thank Lucy Conner for coordinating the fieldwork. AirBoxLab (Foobot) partially funded this study by offering a discount on the air monitors used in this research.

Conflicts of Interest: The authors declare no conflict of interest.

\section{References}

1. US EPA. Introduction to Indoor Air Quality; United States Environmental Protection Agency: Washington, DC, USA, 2021.

2. Cincinelli, A.; Martellini, T. Indoor air quality and health. Int. J. Environ. Res. 2017, 14, 1286. [CrossRef]

3. US EPA. A Guide to Indoor Air Quality. 2021. Available online: https://www.epa.gov/indoor-air-quality-iaq/inside-storyguide-indoor-air-quality (accessed on 27 July 2021).

4. Pietrogrande, M.C.; Casari, L.; Demaria, G.; Russo, M. Indoor air quality in domestic environments during periods close to Italian COVID-19 lockdown. Int. J. Environ. Res. Public Health 2021, 18, 4060. [CrossRef] [PubMed]

5. Campagnolo, D.; Saraga, D.E.; Cattaneo, A.; Spinazze, A.; Mandin, C.; Mabilia, R.; Perreca, E.; Sakellaris, I.; Canha, N.; Mihucz, V.G.; et al. VOCs and aldehydes source identification in European office buildings-The OFFICAIR study. Build. Environ. 2017, 115, 18-24. [CrossRef]

6. Spinazzè, A.; Campagnolo, D.; Cattaneo, A.; Urso, P.; Sakellaris, I.A.; Saraga, D.E.; Mandin, C.; Canha, N.; Mabilia, R.; Perreca, E.; et al. Indoor gaseous air pollutants determinants in office buildings-The OFFICAIR project. Indoor Air 2020, 30 , 76-87. [CrossRef]

7. Sérafin, G.; Blondeau, P.; Mandin, C. Indoor air pollutant health prioritization in office buildings. Indoor Air 2021, 31, 646-659. [CrossRef]

8. He, C.; Morawska, L.; Taplin, L. Particle emission characteristics of office printers. Environ. Sci. Technol. 2007, 41, 6039-6045. [CrossRef]

9. Destaillats, H.; Maddalena, R.L.; Singer, B.C.; Hodgson, A.T.; McKone, T. Indoor pollutants emitted by office equipment: A review of reported data and information needs. Atmos. Environ. 2008, 42, 1371-1388. [CrossRef]

10. Weschler, C.J. Changes in indoor pollutants since the 1950s. Atmos. Environ. 2009, 43, 153-169. [CrossRef]

11. Nag, P.K. Sick Building Syndrome and Other Building-Related Illnesses. In Office Building; Springer: Singapore, $2019 ;$ pp. 53-103.

12. Mandin, C.; Trantallidi, M.; Cattaneo, A.; Canha, N.; Mihucz, V.G.; Szigeti, T.; Mabilia, R.; Perreca, E.; Spinazzè, A.; Fossati, S.; et al. Assessment of indoor air quality in office buildings across Europe-The OFFICAIR study. Sci. Total Environ. 2017, 579, 169-178. [CrossRef]

13. Vesitara, R.A.K.; Surahman, U. Sick building syndrome: Assessment of school building air quality. J. Phys. Conf. Ser. 2019, 1375, 012087. [CrossRef]

14. Rackes, A.; Waring, M. Do time-averaged, whole-building, effective volatile organic compound (VOC) emissions depend on the air exchange rate? A statistical analysis of trends for 46 VOC s in US offices. Indoor Air 2016, 26, 642-659. [CrossRef] [PubMed]

15. Balvers, J.; Bogers, R.; Jongeneel, R.; van Kamp, I.; Boerstra, A.; van Dijken, F. Mechanical ventilation in recently built Dutch homes: Technical shortcomings, possibilities for improvement, perceived indoor environment and health effects. Archit. Sci. Rev. 2012, 55, 151. [CrossRef]

16. D'Antonio, P. Combatting IAQ and health concerns: There are many ways to improve indoor air quality in buildings and to address COVID-19 fears. Consult. Specif. Eng. 2021, 58, 14-19.

17. Bernstein, J.A.; Alexis, N.; Bacchus, H.; Bernstein, I.L.; Fritz, P.; Horner, E.; Li, N.; Mason, S.; Nel, A.; Oullette, J.; et al. The health effects of nonindustrial indoor air pollution. J. Allergy Clin. Immunol. 2008, 121, 585-591. [CrossRef]

18. Svendsen, E.R.; Gonzales, M.; Commodore, A. The role of the indoor environment: Residential determinants of allergy, asthma and pulmonary function in children from a US-Mexico border community. Sci. Total. Environ. 2018, 616, 1513-1523. [CrossRef] [PubMed] 
19. Holgate, S.; Grigg, J.; Agius, R.; Ashton, J.R.; Cullinan, P.; Exley, K.; Fishwick, D.; Fuller, G.; Gokani, N.; Griffiths, C.; et al. Every Breath We Take: The Lifelong Impact of Air Pollution, Report of a Working Party; Royal College of Physicians: London, UK, 2016.

20. Joshi, S.M. The sick building syndrome. Indian J. Occup. Environ. Med. 2008, 12, 61-64. [CrossRef]

21. Wolkoff, P.; Azuma, K.; Carrer, P. Health, work performance, and risk of infection in office-like environments: The role of indoor temperature, air humidity, and ventilation. Int. J. Hyg. Environ. Health 2021, 233, 113709. [CrossRef]

22. Bluyssen, P.M.; Roda, C.; Mandin, C.; Fossati, S.; Carrer, P.; De Kluizenaar, Y.; Mihucz, V.G.; de Oliveira Fernandes, E.; Bartzis, J. Self-reported health and comfort in 'modern' office buildings: First results from the European OFFICAIR study. Indoor Air 2016, 26, 298-317. [CrossRef] [PubMed]

23. Pitarma, R.; Marques, G.; Ferreira, B.R. Monitoring indoor air quality for enhanced occupational health. J. Med. Syst. 2017, 41, 1-8. [CrossRef] [PubMed]

24. Carrer, P.; Wolkoff, P. Assessment of indoor air quality problems in office-like environments: Role of occupational health services. Int. J. Environ. Res. Public Health 2018, 15, 741. [CrossRef]

25. Feng, S.; Gao, D.; Liao, F.; Zhou, F.; Wang, X. The health effects of ambient $\mathrm{PM}_{2.5}$ and potential mechanisms. Ecotoxicol. Environ. Saf. 2016, 128, 67-74. [CrossRef]

26. Chen, H.; Burnett, R.T.; Kwong, J.C.; Villeneuve, P.J.; Goldberg, M.S.; Brook, R.D.; van Donkelaar, A.; Jerrett, M.; Martin, R.V.; Brook, J.R.; et al. Risk of incident diabetes in relation to long-term exposure to fine particulate matter in Ontario, Canada. Environ. Health Perspect. 2013, 121, 804-810. [CrossRef] [PubMed]

27. Fleischer, N.L.; Merialdi, M.; van Donkelaar, A.; Vadillo-Ortega, F.; Martin, R.V.; Betran, A.P.; Souza, J.P.; O’Neill, M.S. Outdoor air pollution, preterm birth, and low birth weight: Analysis of the world health organization global survey on maternal and perinatal health. Environ. Health Perspect. 2014, 122, 425-430. [CrossRef] [PubMed]

28. Wolkoff, P. Indoor air pollutants in office environments: Assessment of comfort, health, and performance. Int. J. Hyg. Environ. Health 2013, 216, 371-394. [CrossRef]

29. Asikainen, A.; Carrer, P.; Kephalopoulos, S.; de Oliveira Fernandes, E.; Wargocki, P.; Hänninen, O. Reducing burden of disease from residential indoor air exposures in Europe (HEALTHVENT project). Environ. Health 2016, 15, 61-72. [CrossRef]

30. Vilhelmson, B.; Thulin, E. Who and where are the flexible workers? Exploring the current diffusion of telework in Sweden. New Technol. Work. Employ 2016, 31, 77-96. [CrossRef]

31. Dingel, J.I.; Neiman, B. How many jobs can be done at home? J. Public Econ. 2020, 189, 104235. [CrossRef]

32. Boeri, T.; Caiumi, A.; Paccagnella, M. Mitigating the work-safety trade-off. Covid Econ. 2020, 2, 60-66.

33. Jones, J.M. In US, Telecommuting for Work Climbs to 37\%. Gallup News. 2015. Available online: https://news.gallup.com/poll/ 184649 / telecommuting-work-climbs.aspx (accessed on 5 December 2021).

34. Rudolph, C.W.; Baltes, B.B. Age and health jointly moderate the influence of flexible work arrangements on work engagement: Evidence from two empirical studies. J. Occup. Health Psychol. 2017, 22, 40. [CrossRef] [PubMed]

35. Conradie, W.J.; De Klerk, J.J. To flex or not to flex? Flexible work arrangements amongst software developers in an emerging economy. SA J. Hum. Resour. Manag. 2019, 17, 1-12. [CrossRef]

36. Okuyan, C.B.; Begen, M.A. Working from home during the COVID-19 pandemic, its effects on health, and recommendations: The pandemic and beyond. Perspect. Psychiatr. Care 2021. Available online: https:// onlinelibrary.wiley.com/doi/full/10.1111/ppc.12 847 (accessed on 8 December 2021).

37. Reznik, J.; Hungerford, C.; Kornhaber, R.; Cleary, M. Home-based work and ergonomics: Physical and psychosocial considerations. Issues Ment. Health Nurs. 2021. [CrossRef]

38. Wang, B.; Liu, Y.; Qian, J.; Parker, S.K. Achieving effective remote working during the COVID-19 pandemic: A work design perspective. Appl. Psychol. 2021, 70, 16-59. [CrossRef]

39. Hu, D.S.; Azhar, E.I.; Madani, T.A.; Ntoumi, F.; Kock, R.; Dar, O.; Ippolito, G.; Mchogh, T.D.; Memish, Z.; Drosten, C.; et al. The continuing 2019-nCoV epidemic threat of novel coronaviruses to global health-The latest 2019 novel coronavirus outbreak in Wuhan, China. Int. J. Infect. Dis. 2020, 91, 264-266. [CrossRef] [PubMed]

40. US CDC. Laboratory-Confirmed COVID-19- Associated Hospitalizations. 2020. Available online: https://gis.cdc.gov/grasp/ COVIDNet/COVID19_3.html (accessed on 27 July 2021).

41. Thompson, R. Pandemic potential of 2019-nCoV. Lancet Infect Dis. 2020, 20, 280. [CrossRef]

42. Koren, M.; Pető, R. Business disruptions from social distancing. PLoS ONE 2020, 15, e0239113. [CrossRef] [PubMed]

43. Mongey, S.; Pilossoph, L.; Weinberg, A. Which workers bear the burden of social distancing? J. Econ. Inequal. 2021, 19, 509-526. [CrossRef]

44. U.S. Bureau of Labor Statistics. Ability to Work from Home: Evidence from Two Surveys and Implications for the Labor Market in the COVID-19 Pandemic. 2020. Available online: https://www.bls.gov/opub/mlr/2020/article/ability-to-work-from-home.htm. (accessed on 20 November 2021).

45. Barrot, J.N.; Grassi, B.; Sauvagnat, J. Sectoral effects of social distancing. AEA Pap. Proc. 2021, 111, 277-281. [CrossRef]

46. Koohsari, M.J.; Nakaya, T.; Shibata, A.; Ishii, K.; Oka, K. Working from home after the COVID-19 pandemic: Do company employees sit more and move less? Sustainability 2021, 13, 939. [CrossRef]

47. Brynjolfsson, E.; Horton, J.; Ozimek, A.; Rock, D.; Sharma, G.; Tuye, H.Y. COVID-19 and Remote Work: An Early Look at US Data; National Bureau of Economic Research: Cambridge, MA, USA, 2020. 
48. Deng, Z.; Morissette, R.; Messacar, D. Running the Economy Remotely: Potential for Working from Home during and after COVID-19. Statistics Canada Catalogue. 2021. Available online: https://www150.statcan.gc.ca/n1/pub/45-28-0001/2020001 /article/00026-eng.htm (accessed on 5 December 2021).

49. De Haas, M.; Faber, R.; Hamersma, M. How COVID-19 and the Dutch intelligent lockdown change activities, work and travel behaviour: Evidence from longitudinal data in the Netherlands. Transp. Res. Interdiscip. Perspect. 2020, 6, 100150. [CrossRef]

50. Alonso, M.J.; Jørgensen, R.B.; Mathisen, H.M. Short term measurements of indoor air quality when using the home office in Norway. E3S Web Conf. 2021, 246, 01002. [CrossRef]

51. Moreno-Rangel, A.; Baek, J.; Roh, T.; Xu, X.; Carrillo, G. Assessing impact of household intervention on indoor air quality and health of children with asthma in the US-Mexico border: A pilot study. J. Environ. Public Health 2020, 2020, 6042146. [CrossRef] [PubMed]

52. Sousan, S.; Koehler, K.; Hallett, L.; Peters, T.M. Evaluation of consumer monitors to measure particulate matter. J. Aerosol Sci. 2017, 107, 123-133. [CrossRef]

53. Moreno-Rangel, A.; Sharpe, T.; Musau, F.; McGill, G. Field evaluation of a low-cost indoor air quality monitor to quantify exposure to pollutants in residential environments. J. Sens. Sens. Syst. 2018, 7, 373-388. [CrossRef]

54. Spinazzè, A.; Borghi, F.; Rovelli, S.; Mihucz, V.G.; Bergmans, B.; Cattaneo, A.; Cavallo, D.M. Combined and Modular Approaches for Multicomponent Monitoring of Indoor air Pollutants. Available online: https://www.tandfonline.com/doi/full/10.1080/05 704928.2021.1995405 (accessed on 8 December 2021).

55. Moreno-Rangel, A. Continuous IAQ Monitoring with Low-Cost Monitors: Protocol Development, Performance and Application in Residential Buildings; The Glasgow School of Art: Glasgow, UK, 2019.

56. Moreno-Rangel, A.; Sharpe, T.; Musau, F.; McGill, G. Indoor fine particle $\left(\mathrm{PM}_{2.5}\right)$ pollution and occupant perception of the indoor environment during summer of the first Passivhaus certified dwelling in Latin America. J. Nat. Resour. Dev. 2018, 8, 78-90. [CrossRef]

57. Whitehead, C.; Robertson, A.; Burge, S.; Kely, C.; Leinster, P. A Questionnaire for Studies of Sick Building Syndrome: A Report to The Royal Society of Health Advisory Group on Sick Building Syndrome; Building Research Establishment Report: Watford, UK, 1995.

58. Berglund, B.; Brunekreef, B.; Knöppe, H.; Lindvall, T.; Maroni, M.; Mølhave, L.; Skov, P. Effects of Indoor Air Pollution on Human Health. Report No. 10. European Concerted Action: Indoor Air Quality and Its Impact on Man; Eauropean Commission Report: Luxembourg, 1991.

59. Berglund, B.; Bluyssen, P.; Clausen, G.; Garriga-Trillo, A.; Gunnarsen, L.; Knöppel, H.; Lindvall, T.; MaclEOD, P.; Mølhave, L.; Winneke, G. Sensory Evaluation of Indoor Air Quality. Report No. 20. European Collaborative Action: Indoor Air Quality and Its Impact on Man; European Commission Report: Luxembourg, 1999.

60. ANSI/ASHRAE. Standard 55-2013: Thermal Environmental Conditions for Human Occupancy; National Standards Institute/American Society of Heating, Refrigerating, and Air-Conditioning Engineers: Atlanta, GA, USA, 2013.

61. US EPA. Indoor Air Qqulity Tools for Schools Action Kit, EPA 402/K-07/008; United States Environmental Protection Agency: Washington, DC, USA, 2009.

62. US EPA. NAAQS Table. 2021. Available online: https://www.epa.gov/criteria-air-pollutants/naaqs-table (accessed on 12 October 2021).

63. US GBC. LEED v4.1: Indoor Environmental Quality Performance. US Green Building Council: Washington, DC, USA, 2021. Available online: https://www.usgbc.org/credits/existing-buildings-schools-existing-buildings-retail-existing-buildings-datacenters-5 (accessed on 12 October 2021).

64. Venter, Z.S.; Aunan, K.; Chowdhury, S.; Lelieveld, J. Air pollution declines during COVID-19 lockdowns mitigate the global health burden. Environ. Res. 2021, 192, 110403. [CrossRef] [PubMed]

65. Ghahremanloo, M.; Choi, Y.; Sayeed, A.; Salman, A.K.; Pan, S.; Amani, M. Estimating daily high-resolution $\mathrm{PM}_{2 .} 5$ concentrations over Texas: Machine Learning approach. Atmos. Environ. 2021, 247, 118209. [CrossRef]

66. Xiao, Y.; Becerik-Gerber, B.; Lucas, G.; Roll, S.C. Impacts of working from home during COVID-19 pandemic on physical and mental well-being of office workstation users. J. Occup. Environ. Med. 2021, 63, 181-190. [CrossRef]

67. Ferrante, G.; Mollicone, D.; Cazzato, S.; Lombardi, E.; Pifferi, M.; Turchetta, A.; Tancredi, G.; La Grutta, S. COVID-19 pandemic and reduced physical activity: Is there an impact on healthy and asthmatic children? Front. Pediatr. 2021, 9, 695703. [CrossRef] 